Illinois State University

ISU ReD: Research and eData

Theses and Dissertations

$10-17-2014$

\title{
Moderators of the Relationship Between Perceived Employability and Voluntary Turnover
}

Joseph Kenneth Morrison

Illinois State University, jmorrison1014@gmail.com

Follow this and additional works at: https://ir.library.illinoisstate.edu/etd

Part of the Vocational Rehabilitation Counseling Commons

\section{Recommended Citation}

Morrison, Joseph Kenneth, "Moderators of the Relationship Between Perceived Employability and Voluntary Turnover" (2014). Theses and Dissertations. 278.

https://ir.library.illinoisstate.edu/etd/278

This Thesis is brought to you for free and open access by ISU ReD: Research and eData. It has been accepted for inclusion in Theses and Dissertations by an authorized administrator of ISU ReD: Research and eData. For more information, please contact ISUReD@ilstu.edu. 


\title{
MODERATORS OF THE RELATIONSHIP BETWEEN PERCEIVED EMPLOYABILITY AND VOLUNTARY TURNOVER
}

\author{
Joseph K. Morrison
}

61 Pages

December 2014

This thesis reports a quantitative research project examining the relation between perceived employability and voluntary turnover and the moderating roles played by job embeddedness and perceived organizational support. This examination uses archival data from 230 participants from a multinational organization using zero-order correlations and moderated binary logistic regression techniques. Significant correlational effects were found between perceived employability and voluntary turnover. Significant moderated logistic regression effects were found when adding job embeddedness and perceived organizational support to the perceived employability and voluntary turnover logistic regression model. Following the results is a discussion of the implications of this research, both theoretically and practically, as well as limitations and future research. 
MODERATORS OF THE RELATIONSHIP BETWEEN PERCEIVED

\section{EMPLOYABILITY AND VOLUNTARY TURNOVER}

JOSEPH K. MORRISON

A Thesis Submitted in Partial

Fulfillment of the Requirements for the Degree of

MASTER OF SCIENCE

Department of Psychology

ILLINOIS STATE UNIVERSITY

2014 
(C) 2014 Joseph K. Morrison 
MODERATORS OF THE RELATIONSHIP BETWEEN PERCEIVED EMPLOYABILITY AND VOLUNTARY TURNOVER

JOSEPH K. MORRISON

COMMITTEE MEMBERS:

Dan Ispas, Chair

Kimberly Schneider 


\section{ACKNOWLEDGMENTS}

I would like to thank my committee members, Drs. Dan Ispas and Kimberly Schneider, for their patience and perceptive reviews as well as their dedication in assisting me throughout this thesis project. I will always hold an enormous amount of gratitude for their help, time, and effort.

I also would like to extend a great thank you to Alexandra Ilie and Dragos Iliescu for providing me with the data for this thesis study.

This thesis is dedicated to my unendingly patient wife, Jackie, for pushing me through the hard and seemingly endless days and nights attempting to finish this project. I would also like to dedicate it to my parents for giving me anything and everything I needed to succeed in both my education and my life to get where I am today. I could not be more thankful.

Lastly, I would like to thank Josh Rohlfs for taking my late night calls and for having the patience to help me.

J.K.M. 


\section{CONTENTS}

Page

ACKNOWLEDGMENTS $\quad$ i

CONTENTS

TABLES

FIGURES

CHAPTERS

I. INTRODUCTION: THE PROBLEM AND ITS BACKGROUND 1

Statement of the Problem 1

Purpose 4

II. REVIEW OF RELATED LITERATURE

$\begin{array}{ll}\text { General Literature Review } & 7\end{array}$

Perceived Employability $\quad 7$

Voluntary Turnover $\quad 11$

Perceived Employability and Voluntary Turnover 23

Job Embeddedness as a Moderator in the Relation between Perceived

Employability and Voluntary Turnover 25

Perceived Organizational Support as a Moderator in the Relation between

Perceived Employability and Voluntary Turnover 29

$\begin{array}{ll}\text { Hypotheses } & 32\end{array}$

III. RESEARCH DESIGN 34

$\begin{array}{ll}\text { Method } & 34\end{array}$

Participants $\quad 34$

$\begin{array}{ll}\text { Measures } & 34\end{array}$ 
IV. ANALYSES AND RESULTS

V. DISCUSSION

Summary of Findings

49

Theoretical and Practical Implications

51

Limitations

52

Future Research

REFERENCES 


\section{TABLES}

Table

1. Reliabilities, Means, Standard Deviations, and Intercorrelations

2. Moderated Logistic Regression Analysis Results Predicting Voluntary Turnover From Perceived Employability, Job Embeddedness, and the Perceived Employability by Job Embeddedness Interaction (A)

3. Moderated Logistic Regression Analysis Results Predicting Voluntary Turnover From Perceived Employability, Job Embeddedness, and the Perceived Employability by Job Embeddedness Interaction (B)

4. Moderated Logistic Regression Analysis Results Predicting Voluntary Turnover From Perceived Employability, Perceived Organizational Support, and the Perceived Employability by Perceived Organizational Support Interaction (A) 46

5. Moderated Logistic Regression Analysis Results Predicting Voluntary Turnover From Perceived Employability, Perceived Organizational Support, and the Perceived Employability by Perceived Organizational Support Interaction (B) 


\section{FIGURES}

Figure $\quad$ Page

1. Plot of Two-way Logistic Interaction between Perceived Employability and Job Embeddedness

2. Plot of Two-way Logistic Interaction between Perceived Employability and Perceived Organizational Support 


\section{CHAPTER I}

\section{INTRODUCTION: THE PROBLEM AND ITS BACKGROUND}

\section{Statement of the Problem}

In the past few decades, the workforce has seen a shift. One of the main components in this shift is that of adaptability. Those with more experiences and jobs are seen in a more favorable light than in previous years. This can affect one's job opportunities, whether that be getting a new job, being promoted to a new position, or even whether they maintain their current job (Forrier, Sels, \& Stynen, 2009; Kinnunen, Mäkikangas, Mauno, Siponen, \& Nätti, 2011; Rothwell, Jewell, \& Hardie, 2009). This newer emphasis on adaptive employees that may have had multiple jobs contradicts previous cultural views on work ethic, which have implied that frequently changing jobs is an indication of poor character (Barrick \& Zimmerman, 2009). Having a sense of how employable one is can affect "the individual's beliefs about how easy it is to find new employment” (De Cuyper, Mauno, Kinnunen, \& Mäkikangas, 2011a, p. 253) and, reflecting the shifting workforce idea, the concept of not having a job for life is a prevalent thought among present day employees (Forrier et al., 2009).

A person's sense of his or her ability to be successfully employed is known as perceived employability. Perceived employability has been found to predict important outcomes including job exhaustion (De Cuyper et al., 2011a), performance (Kinnunen et 
al., 2011), and adaptability (Ito \& Brotheridge, 2005). If an employer can measure perceived

employability, they may be able to see how much potential an individual holds and how much demand for the individual there is in their specific market (De Cuyper et al., 2011a). Perceived employability also represents how the person perceives his or her qualification level and whether or not certain jobs match this level (Rothwell et al., 2009). Obviously employers are looking to fill a job utilizing the individual with the highest potential, but conversely, a highly employable person may be seen as one who is more prone to seek other employment due to various outside opportunities (Berntson, Sverke, \& Marklund, 2006; De Cuyper et al., 2011a). In short, these individuals have great potential not only in the eyes of the current employer" but also of other prospective employers.

Overall, an individual's perceived employability can be a gateway into seeing not only how much potential he or she may have, but also whether he or she may be a flight risk (Ito \& Brotheridge, 2005). For this reason, perceived employability, rather than employability alone, is an important concept to research; it shows how well the individual knows how easily he or she could find other jobs. All employees could theoretically be on the look out for other opportunities, regardless of whether they have seriously considered leaving or how much the organization has tried to prevent such thoughts. It is vital for employers to deter high performing employees' thoughts of leaving (dysfunctional turnover) and to encourage low performing employees' thoughts of leaving (functional turnover), which brings to light one of the most significant challenges that organizations must face (Boswell, Run Ren, \& Hinrichs, 2008; Holtom, Mitchell, 
Lee, \& Eberly, 2008). With the current labor market being so tight, hanging on to highly effective employees is harder than ever.

An important concept to which perceived employability can be applied is succession planning. According to Fernández-Aráoz, Groysberg, and Nohria (2011), only $15 \%$ of companies in North America and Asia say they have enough employees that would be suitable to replace their current key employees. To combat this, companies attempt to pinpoint the high potential employees in the company and prepare them via succession planning. Succession planning entails predicting which key employees will be most effective for future management and executive roles (Kesler, 2002). In order to do this, current managers and executives must have certain criteria to assess effectively their employees' potential for success, both before and after hiring.

In order to bolster the use of effective succession planning and employee promotion processes in general, there should be a set of predictors identified for each organization that would forecast the success of an upcoming employee. Additionally, according to Mintzberg (1989), many organizations base their selection and promotional decisions solely on educational accomplishments. Replacing executives with employees who appear to have potential only because of a certain educational degree is a dangerous trend that can be solved by constructing processes with reliable, nonacademic predictors. Being able to proactively use perceived employability to accurately predict whether an employee will be more likely to turnover may be a crucial criterion for employee selection and promotion. Lastly, retaining human capital in general is a key concern for organizations, and any results found here could be beneficial for this reason (Boswell et al., 2008). 
Another important reason to consider perceived employability as a criterion is that it is known to decrease employee vulnerability to workplace stressors and make them less susceptible to deleterious outcomes such as burnout (De Cuyper, Raedner, Van der Heijden, \& Wittekind, 2012) thereby decreasing likelihood of quitting (Jackson, Schwab, \& Schuler, 1986; Mor Barak, Nissly, \& Levin, 2001). However, perceived employability can also predict outcomes in the opposite direction, such as when employees perceive themselves as highly employable and seek out other opportunities, thereby increasing likelihood of quitting (Briscoe \& Hall, 2006; Buss, 2008). This contradiction in the literature is a main focus for this research study.

Additionally, while much of the literature presents evidence that perceived employability relates positively with turnover rate (e.g. Steel \& Griffeth, 1989), there remain inconsistencies in the research. One side of the literature has gone so far as to state that perceived employability is “....individuals" perceptions of their chances of obtaining a new job" (Kinnunen et al., 2011, p. 141). Whether these perceptions are based on such characteristics as self-efficacy or external opportunities, this definition implies that turnover is integrally related to perceived employability. Other literature has indicated that perceived employability is less correlated with turnover than once thought, reporting correlation coefficients as low as $r=.12$. There may be multiple variables affecting the relation, lowering the main effect between perceived employability and turnover (Berntson et al., 2006).

\section{Purpose}

To answer the previous problems, the purpose of this study was to address the aforementioned inconsistencies and to examine new moderators of the perceived 
employability-turnover relationship. In their meta-analysis, Griffeth, Hom, and Gaertner (2000) specifically called for a greater focus on moderators in the study of employee turnover. In part, as a response to Griffeth and colleagues, I developed this study to investigate the moderating effects job embeddedness and perceived organizational support have on the relation between perceived employability and voluntary turnover.

Largely based in employee motivation, job embeddedness is defined as an employee's desire to stay in his or her current position and job (Boswell et al., 2008). This motivation is primarily governed by the perception of loss the employee would face when moving away from his or her present social, psychological, and financial state (Clinton, Knight, \& Guest, 2012). Importantly, job embeddedness pushes the employee to believe that it is his or her job to not quit the organization.

Similarly, perceived organizational support can lead to feelings of obligation to the organization. However, the difference is in the source of the felt obligation as it is derived specifically from the aggregate of the organization, such as supervisors or coworkers (Eisenberger, Huntington, Hutchison, \& Sowa, 1986). For example, an employee may express that the organization cares for him or her and has his or her best interests in mind. The organization is not one being, but it is easy to aggregate the many moving parts and create a broad summary of its many constituents. Perceived organizational support stems from the organization's tendency to care about the wellbeing of the employee. Eisenberger and colleagues (1986) go on to state that the amount of perceived organizational support is dependent on how much the employee views the organization as recognizing and caring about his or her contributions. 
Job embeddedness and perceived organizational support both contribute to this research study when examining the intricacies of the perceived employability-voluntary turnover relation. I will go on to examine the evidence that led me to believe these two variables have a moderating effect on this relation. 
CHAPTER II

\section{REVIEW OF RELATED LITERATURE}

\section{General Literature Review}

\section{Perceived Employability}

There has been a notable shift in the labor market such that employees who once performed narrow, well-defined jobs, are now expected to perform a multitude of tasks (Boswell et al., 2008). With increasingly varied duties, more pressure is placed on the individual to appear competent and able to fulfill such roles. The notion of employability describes an employee's ability "to maintain and enhance [his or her]...attractiveness in the labor market" (Rothwell \& Arnold, 2007, p. 24). When breaking the word apart literally, it yields the words employment and ability, which in itself provides a clear definition. Add on to this the notion of perceived employability, which implies the individual's self-perception of being employable (De Cuyper et al., 2011a).

De Cuyper and colleagues (2012b) and Rothwell and colleagues (2009) go on to explain that perceived employability is one of two ways to interpret employability. It is able to relate employability to inputs that help the employee obtain and stay in that job (such as knowledge, skills, and abilities), and it describes the self-perceptions the employee has of his or her own employability (perceived employability). Since perceived employability is so focused on the self and is relatively stable over time, it has not been found to change significantly in various situations, thereby accounting for contextual 
variability plaguing many organizational behavior studies (De Cuyper et al., 2012b). Perceived employability is a unitary construct, and while perceived employability has been broken down into two separate constructs, namely internal and external (Rothwell \& Arnold, 2007), it is simpler and better-validated when using a unitary conceptualization. Therefore, this thesis upholds perceived employability as a unitary concept.

Much of the literature on perceived employability has stemmed from research done by March and Simon (1958) and Mobley and colleagues (1979), which discussed the parallel concepts of perceived ease of movement and perceived alternatives (respectively). Perceived ease of movement is usually conceptualized as the employee's perceived ability to be able to switch jobs easily (De Cuyper et al., 2011a). Similarly, perceived alternatives can be defined as the quantity and quality of an employee's job alternatives (Steel \& Griffeth, 1989).

Perceived employability has been conceptualized as a personal resource in which employees have the ability to hold onto their jobs and to manipulate their surrounding environments (De Cuyper et al., 2012b). This fits with Hobfoll's (2001) Conservation of Resources Theory in which people who have higher personal resources have a higher likelihood of receiving back those and other resources. This means that highly employable people can be protected against problems such as burnout. De Cuyper and colleagues (2012a) provided evidence supporting the Conservation of Resources Theory by showing that high perceived employability (through reduced job insecurity) lowered employees' susceptibility to exhaustion, a major factor of burnout. Employees were therefore less likely to underperform in their positions and more likely to retain their jobs (De Cuyper et al., 2012a). 
Related to burnout and exhaustion, Kinnunen and colleagues (2011) presented perceived employability from the perspective of Lazarus and Folkman's transactional stress theory. They proposed that employees high in perceived employability interpreted environmental demands more positively than those low in perceived employability. Specifically, they viewed them as challenges rather than threats, leading to less stress and therefore to less burnout (Kinnunen et al., 2011). They found that those high in perceived employability had lower job exhaustion, less stress, and generally more positive wellbeing (reflecting the transactional stress model). Following this line of research, Berntson and Marklund (2007) found a general trend of better overall physical and mental health among those higher in perceived employability, possibly because of the increased self-efficacy felt by the employee.

While being high in perceived employability seems positive for employees in general, it may not be as positive for the organization. Though research shows that employees high in perceived employability do perform better (Van der Heijde \& Van der Heijden, 2006), they also think about leaving their jobs for other organizational opportunities more frequently (De Cuyper et al., 2011b).

Taking into consideration the previous evidence and specifically following De Cuyper and colleagues (2011b), the concept of perceived employability becomes intrinsically entwined with turnover due to employee perceptions of the ability to be employed elsewhere. One conceptualization of this idea brings to light a relatively new concept popular in current literature known as the boundaryless and protean worker. It incorporates many of these ideas and demonstrates the change in current organizational dynamics, especially when looking at current perceived employability research. 
The Boundaryless/Protean Worker. Described by Briscoe and Hall (2006), boundaryless and protean workers are not bound to their organizations but instead may consistently switch jobs and job orientations. Some employees fit this description because of factors like financial persuasions or more attractive job opportunities that better fit their values (Sullivan, 1999). They are viewed as particularly strong employees in the present dynamic and shifting workforce because they are oriented toward being highly adaptable. These workers are usually highly employable and have increased movement between jobs and organizations (De Cuyper et al., 2011a). Additionally, boundaryless and protean workers likely have lower commitment to the organizations of which they are a part, thus tying into job embeddedness (De Cuyper et al., 2011a), which will be discussed below.

The changing workforce has strengthened the link between boundaryless and protean workers and high perceived employability in recent years. There has been a change in employment relationships as well as the concept of psychological contracts (Sullivan, 1999). Previously, these informal contracts included aspects such as job security and company paternalism. However, with the advent of the constantly changing nature of careers, some organizations now include aspects of employability and responsibility in their contracts because they expect their employees to fulfill a larger role or greater number of roles in the workplace. From this theoretical perspective, perceived employability can be viewed as breaking the traditional boundaries of employee commitments to their organizations (Rothwell \& Arnold, 2007). This is an important perspective to take into account when comparing traditional concepts of the employeeorganization relationship and especially when trying to predict the stability of new 
employees. Although an organization may want to depend on their current processes and contract obligations, it is crucial for them to consider the motives of the new wave of employees looking for positions and their tendency to consider other opportunities rather than looking solely for one organization to spend the rest of their careers.

\section{Voluntary Turnover}

One of the most common criteria of employee success is performance. Thus, research for selection procedures tends to focus mainly on predicting high performance in employees (Barrick \& Zimmerman, 2009). However, in recent decades, more research has surfaced stating that while performance is important, voluntary turnover rate can be equally, if not more important for choosing the most successful and worthwhile employees due to high replacement costs (Barrick \& Zimmerman, 2009). While it may seem difficult to determine whether an employee is prone to leaving an organization, much research supports that it is possible to predict the likelihood of voluntary turnover. This is not to say that performance is unimportant but rather that focus should not be solely on that criterion. In fact, performance can be used to predict voluntary turnover, which in turn can predict whether an employee is worth hiring (Griffeth et al., 2000).

It should be briefly noted that not all turnover is created equal. When an employee decides to leave an organization for any reason, it is known as voluntary turnover (Holtom et al., 2008). This type of turnover is not usually the first type to come to mind because the higher-profile involuntary turnover (e.g., laying off, firing, etc.) brings forth strong negative connotations and anxiety (Boswell et al., 2008). While both are detrimental in many ways and are important to study, research on voluntary turnover should be taken into greater consideration because it is out of the control of the 
organization (Holtom et al., 2008). Additionally, high performers tend to have more external opportunities available to them and are more likely to voluntarily leave their current job than low performers, thereby creating dysfunctional turnover. Although turnover is generally a negative thought, organizations would often rather have poor performers leave (functional turnover) so as to save the company money (Holtom et al., 2008). Leaders in the organization can decide when to lay off or fire employees, but they have little say in the decisions that employees make if they want to leave. With this in mind, the following sections have a strong emphasis on voluntary turnover but still include aspects of turnover in general.

The likelihood of voluntary turnover is not seen as overtly important in hiring, but it is quite crucial because employees who have been predicted to be turnover threats indirectly affect overall organizational success, regardless of if they perform successfully or poorly. Turnover has been shown to decrease the overall performance of an organization even when successful performers are present (Glebbeek \& Bax, 2004). On one side, this is seen in hiring employees whose performance is minimal and lowfunctioning. It can be detrimental to pay them because their outputs do not reimburse the organizational inputs (Holtom et al., 2008). On the other side, losing successful employees is detrimental not only to overall organizational success, but to other individuals who relied on that high performer. Either way, the costs of recruiting, hiring, and training can be extremely high, whether it results in losing a potentially high performer or wasting time and money with a potentially low performer (Barrick \& Zimmerman, 2009). Moreover, it is common for employees to turn over early on in their tenure with the organization, making their return on investment minimal (Muchinsky \& 
Tuttle, 1979). Preventing this is not an easy task and must be taken into consideration before any candidates are put through the selection process.

It is critical for organizations to predict turnover ahead of time so as to eliminate the hiring of individuals who are prone to turning over. Distinguishing constructs that have the ability to predict turnover allows the organization to focus only necessary resources on selection, simultaneously saving money and selecting effective, long-term employees (Barrick \& Zimmerman, 2009). Although it would be ideal to hear directly from potential employees as to whether they are prone to turning over, it is difficult to directly ask this in interviews or self-reports. Instead, research points to a multitude of important variables that can identify the potential turnover risk of certain employees.

Before discussing the prediction of turnover, a brief discussion of turnover concepts is helpful. Although research has covered this topic fairly extensively, it must be noted that each type of organization and even each individual organization is affected differently by turnover (Holtom et al., 2008). This is important to consider when trying to distinguish effective methods of generalizing turnover at the organizational level. Theories such as Mobley's (1977) Intermediate Linkages Model, Sheridan and Abelson's (1983) Cusp Catastrophe Model, and Lee and Mitchell's Unfolding Model (Lee, Mitchell, Wise, \& Fireman, 1996), have been found to successfully generalize at an organizational level.

In the past 15 years, a major trend has been to focus on contextual variables such as interpersonal relationships, organizational support, organizational commitment, and job embeddedness (Barrick \& Zimmerman, 2009; Boswell et al., 2008; Clinton et al.,, 2012; Cross \& Travaglione, 2004; DeConinck \& Johnson, 2009; Griffeth et al., 2000; 
Holtom et al., 2008; Ito \& Brotheridge, 2005; Zagenczyk, Gibney, Few, \& Scott, 2011). These variables help shed light on the details of turnover in organizations and characterize why some turnover is event-based or shock-driven (Holtom et al., 2008; Mobley, 1977) and other turnover processes occur more gradually, resulting from the effects of generalized variables such as satisfaction, support, or embeddedness (Holtom et al., 2008).

Research focusing on contextual variables has been attuned to employees' cognitions of their ability and desire to move positions across organizations (March \& Simon, 1958; Mobley, 1977; Mobley, Griffeth, Hand, \& Meglino, 1979). In some cases, research has found that individuals may be predisposed to turning over even before they begin their jobs (Boswell et al., 2008). This is where additional variables become crucial in describing certain turnover behaviors and ways to predict them. In the upcoming sections, some of these variables are described.

Job Embeddedness and Voluntary Turnover. Holtom and colleagues (2008) stated that researchers have largely been focused on why employees leave and should be equally focused on why certain employees stay. The concept of job embeddedness is largely based on the motivations of employees that influence the desire to stay in their current positions and jobs (Boswell et al., 2008). Job embeddedness has additionally been conceptualized as the perception of difficulty when moving out of one's present social, psychological, and financial state (Clinton et al., 2012). While it has been found that factors such as high job satisfaction ingrain (embed) employees in their organizations (De Cuyper et al., 2011a), further research has shown even stronger underlying factors. These desires to stay are more likely to include innate feelings that push the employee to 
believe that it is his or her job to not quit as well as to remain committed to the organization (Barrick \& Zimmerman, 2009).

Job embeddedness has commonly been broken down into three dimensions, which I will now describe. The first dimension is links, which describes the networks and relationships the employee has with others. The second dimension is fit, which describes how comfortable the person feels within their position, environment, or community. Lastly, the sacrifice dimension describes an employee's perception of how much he or she would lose (be it material or psychological) upon leaving the organization. Additionally, these dimensions are applied both on and off of the job (onthe-job embeddedness and off-the-job embeddedness, respectively). On-the-job embeddedness relates to how much the employee is ingrained in the organization and is taken in conjunction with off-the-job embeddedness, which refers to how enmeshed the employee is in his or her community outside of work (Crossley, Bennett, Jex, \& Burnfield, 2007). While it may overtly seem unrelated to look at the employee's outside community involvement, that community can create ties of which the employee has a hard time letting go. This transfers to the workplace by affecting the likelihood that he or she will stay in the current job, regardless of satisfaction. Taking the first three dimensions along with both types of job embeddedness into account creates a total of six separate dimensions that overall create a composite measure of job embeddedness (Clinton et al., 2012).

However, this way of measuring job embeddedness has been reconsidered because it assumes that the whole is equal to the sum of its parts. Crossley and colleagues (2007) stress that the whole is greater than the sum of those six parts, which is 
why they introduce the notion of global job embeddedness. While the dimensional view only measures the pieces of embeddedness, using a global measure is able to focus on the end product and is able to get a better subjective view of how various respondents weigh the facets of job embeddedness. Additionally, when participants are asked more general questions, they may include information that is relevant but is missing from dimensionallevel scales (Crossley et al., 2007). For these reasons, I have focused on the global measurement conception of job embeddedness.

Like other workplace constructs, job embeddedness exists in employees at varying levels ranging from those who feel little to no attachment to the organization, leading to spontaneous turnover, all the way to those who feel so obligated to maintain their position that they never turnover regardless of work conditions. Earlier organizational literature may have attributed much of this variation to job satisfaction; however, more current research has found that they are in fact separate constructs. Additionally, job embeddedness itself has been found to be a better predictor of turnover than job satisfaction (Griffeth et al., 2000). This finding is corroborated by a recent metaanalytic finding that job embeddedness was negatively associated with actual turnover after controlling for job satisfaction (Jiang, Liu, McKay, Lee, \& Mitchell, 2012).

Ghiselli (1974) pioneered much of this construct's theory when he coined the hobo syndrome, the idea that some employees inherently have the desire to move positions from time to time. Whether it is because they have become bored or because they are never truly happy, Ghiselli (1974) observed that this occurred in particular employees regardless of their level in the organization, their position, or training. However, Ghiselli (1974) did not have a strong argument regarding the reasons for hobo 
syndrome other than anecdotal evidence that there were innate characteristics in certain employees dictating how often they should move. However, much of the "hobo syndrome" can be theoretically explained through job embeddedness (Barrick \& Zimmerman, 2009).

Many other factors seem to be involved in the study of job embeddedness. An important aspect of job embeddedness is the degree to which someone is networked with other employees. The motivation to be more enmeshed in an organization (as mentioned previously) seems to be tied closely with having larger social networks and thus having others come to aid when assistance is needed (Settoon, Bennett, \& Liden, 1996). An employee's sense of belonging can create ties to the organization, thus making him or her less likely to turnover (Richer, Blanchard, \& Vallerand, 2002; Schaufeli \& Bakker, 2004). This connection is one impetus to using job embeddedness and perceived organizational support as moderators in this study, as will be described in further detail later.

Job embeddedness was the topic of a recent meta-analysis by Jiang and colleagues (2012). They found job embeddedness differences between organizational type, cultures, and gender. Examining public versus private organizations, Jiang and colleagues (2012) found a negative relation between on-the-job embeddedness and turnover intentions within public organizations that were significantly stronger than in private organizations. This is explained by the notion that public organizations foster secure and low-risk jobs and value intrinsic factors such as job content. In contrast, private organizations foster competition and are more likely to value extrinsic factors such as income and promotions. The second important finding in Jiang and colleague's (2012) meta-analysis was that 
collectivist cultures showed a significant negative correlation in regards to the relationship between off-the-job embeddedness and turnover intentions, while there was not a significant relationship in individualist cultures. This was attributed to the collectivist mentality that time and effort should be focused on fostering relationships and maintaining healthy communities, thus leading collectivists to respond more strongly to job embeddedness cues and perceive that leaving one's job would be psychologically costly. In contrast, individualist cultures tend to devalue close relationships and focus on advancing individuals through the organization, which can easily bring employees to consider other organizations, leading to fewer concerns about disrupting their relationships with the organization. Lastly, Jiang and colleagues (2012) found that gender was a moderating factor in the relationship between job embeddedness and voluntary turnover. Women had a significantly stronger negative on-the-job embeddedness-actual turnover relationship than did men. This was attributed to a women's higher levels of community and concern for others, as well as limited job opportunities when compared to men. This pushes women to hold onto their current jobs for fear of limited opportunities or upsetting the community (Jiang et al., 2012).

A popular notion is to compare job embeddedness and organizational commitment. They have many similarities and job embeddedness can been viewed as a corollary to the three-component framework of organizational commitment, which consists of a desire (affective commitment), a need (continuance commitment), and an obligation (normative commitment) to the organization (Meyer \& Allen, 1991). The authors explain that this psychological state had implications towards the employee's decision to voluntarily turn over or not. Specifically, affective commitment refers to the 
employee wanting to remain at an organization because he or she feels emotionally attached based on their identification and involvement within the company. An employee with a strong continuance commitment feels that there is a need to remain in the organization because he or she is aware of the costs that leaving would have on his or her life. Lastly, a feeling of normative commitment comes into play when an employee feels obligated to stay, usually to reciprocate investments the organization has made on him or her (Meyer \& Allen, 1991).

All of these can give insight to those employees who feel highly embedded in their organizations (Maertz \& Griffeth, 2004). This embeddedness stems from the feelings of commitment that include a sense of want, need, and obligation an employee feels to the organization and makes thinking about the ramifications of leaving a salient consideration. However, job embeddedness is not organizational commitment (Mitchell, Holtom, Lee, Sablynski, \& Erez, 2001). Inherent in the construct name, it refers only to that commitment that is found for the organization, cutting out much of what job embeddedness comprises (i.e. embeddedness that occurs in the employee's community, outside of the organization). Also, affective commitment refers to the employee's liking of and emotional attachment to his or her position. While this can be a component of job embeddedness, the employee also has non-affective attachments that may fit his or her needs to fulfill his or her position. Additionally, Mitchell and colleagues state that while normative commitment focuses solely on the sense of obligation to the organization, it misses out on the obligation to teams, committees and other, more specific groups and entities. Job embeddedness is able to capture these nuances within the measurement of the construct. Overall, organizational commitment focuses solely on affective content 
while job embeddedness is able to take into account more detailed dimensions of organizational enmeshment (Mitchell et al., 2001).

Along similar lines, Barrick and Zimmerman (2009) found that measures of prehire embeddedness are able to predict voluntary, avoidable turnover later in the employee's career. However, some inconsistencies exist. In one section of their scale that asks whether the individual was referred by a current employee, it was found that job embeddedness and turnover rate were negatively related within the first six months, but became more positively related after the first two years. They theorized that because many people are referred by others, a sense of obligation occurs, which later goes away when they realize they are not obligated to the organization but rather to the reference (Barrick \& Zimmerman, 2009). Because of the evidence presented in the above section on ties of job embeddedness with voluntary turnover, I chose to look for the moderation effects of job embeddedness in addition to the main effects of perceived employability and turnover rate.

Perceived Organizational Support and Voluntary Turnover. When examining studies of general social support, be it supervisor, organizational, or other support, evidence suggests strong interactions between support variables and turnover (Barrick \& Zimmerman, 2009; Cross \& Travaglione, 2004; DeConinck \& Johnson, 2009; De Cuyper et al., 2011a; Eisenberger, Huntington, Hutchison, \& Sowa, 1986; Eisenberger, Stinglhamber, Vandenberghe, Sucharski, \& Rhoades, 2002; Pan \& Yeh, 2012; Rhoades \& Eisenberger, 2002; Zagenczyk, Gibney, Few, \& Scott, 2011). By using more socially focused organizational variables rather than pay-related variables, better commitment and lower turnover rates have been reported (Griffeth et al., 2000). One of 
the important social support constructs reported in the literature is perceived organizational support.

First proposed by Eisenberger and colleagues (1986), perceived organizational support is described as employees" "global beliefs concerning the extent to which the organization values their contributions and cares about their well-being” (p.501). This concept is closely linked to the social relationships an employee has with others, but bases the strength of those relationships on how committed the organization is to the person. Employees are able to identify with their organization and be involved in an emotional unity that either is perceived as supportive or malevolent. Eisenberger and colleagues (1986) go on to state that this anthropomorphic view gives the employee the perception that the organization has dispositional traits. This is due to the amalgamation of many other organizational members' views. In all, the authors stated that perceived organizational support is "influenced by the frequency, extremity, and judged sincerity of statements of praise and approval” (p.501). Additionally, pay, rank, job enrichment, and control over one's own policies affect the amount of organizational support an employee perceives. Such ideas were derived from the norm of reciprocity and effort-outcome expectancy, in which Eisenberger and colleagues (1986) explain that employees will be more committed if the individuals feel they are getting an equal amount of aid for the effort they are providing.

Perceived organizational support is a critical part of employee experience at an organization because it helps the individual identify with that organization (Cross \& Travaglione, 2004). The motivational properties of perceived organizational support have been described as bringing a sense of belonging to an employee within his or her 
organization (Schaufeli \& Bakker, 2004), which helps increase employees' feelings of obligation to that organization (DeConinck \& Johnson, 2009). When these motivational properties are not present, the organization is often unaware of or cannot afford sufficient resources, thereby leading employees to view the organization as unsupportive and to feel a lack of balance between work and home (Pan \& Yeh, 2012). For example, this unsupportiveness may come from the organization's lack of team building activities or additional health and well being services.

A review of the perceived organizational support literature, including a metaanalysis, was conducted by Rhoades and Eisenberger (2002) resulting in a more detailed description of the beneficial aspects of perceived organizational support, which included three categories: fairness, supervisor support, and organizational rewards (including favorable job conditions). Additional analyses indicated strong evidence that high perceived organizational support was related to high affective commitment from the employee, high job satisfaction and general positivity, increased performance, and decreased turnover behaviors and intentions (Eisenberger, Fasolo, \& Davis-LaMastro, 1990; Rhoades \& Eisenberger, 2002). A study from the same year provided additional information on supervisors' roles in representing the organization and helping to reduce turnover (Eisenberger et al., 2002). Perceived organizational support was found to be preceded by perceived supervisor support, which helped give a specific perspective of the organization as a whole. Specifically, when employees felt supported by supervisors of higher status, turnover rate decreased. This implies that those in higher status positions appear to represent more of the organization, thus increasing the employee's perceived organizational support. 
Eisenberger and colleagues (1986) found that those scoring low in perceived organizational support would be the least desirable because they contribute the least to the organization and would be more likely to leave. This was further justified by Zagenczyk and colleagues (2011) who found that employees low in perceived organizational support formed values opposed to those of the organization. These employees misidentified the lack of support and felt less motivated to become a member within the organization. According to Barrick and Zimmerman's (2009) study of hiring for retention and performance, employees are more attracted to an organization that does not foster conflict and does encourage positive emotions. Employees who exhibit these positive emotions are more likely to receive social support and overall are less likely to turnover.

Although there is significant data supporting the relation between perceived organizational support and turnover, one study found some discrepancies. Eisenberger and colleagues (2001) were unable to find significant differences between those who stayed and those who left during a company's downsizing. While the authors noted two reasons for this finding, further examination of the boundary conditions of perceived organizational support should be considered. Because perceived organizational support is closely related to employability and turnover, it makes it an ideal candidate for moderation study.

\section{Perceived Employability and Voluntary Turnover}

Currently, employability has been a focus in the literature because of its consideration as a personal resource. De Cuyper and colleagues (2012b) provided evidence for this that showed that high perceived employability protected against 
burnout. This helps not only the employee, but also the organization in that as burnout decreases, so does the chance of turnover. However, as has been mentioned before, this is potentially not the case. In fact, a growing amount of literature has shown the opposite, in that turnover actually increases when perceived employability is high, which provides the basis of my study.

To begin to explain this perceived employability-turnover main effect in my study, it is prudent to go back to the influential book by March and Simon (1958), in which they detail their theory of organizational equilibrium. This theory states that as long as the organization provides the necessary motivations to perform and remain positive, the employee will stay in the organization. However, they note two particularly important factors that influence employee turnover: the perceived desirability of movement and the perceived ease of movement (both integrally involved with perceived employability). This was followed by both Mobley (1977) and Price (1977) detailing the importance of employees' perceptions of alternative opportunities and how they can affect voluntary turnover risk.

The relation between perceived employability and turnover is explained by many of the concepts that have been previously discussed as well, namely the shifting nature of the workplace. Job insecurity has been an impetus for research that is increasingly relevant in the current workplace (De Cuyper et al., 2011a). This insecurity is observed in current employees and causes many to feel that they cannot rely on their employer/organization to maintain permanence within their position (Forrier et al., 2009). This has spurred the novel thought that they as employees must take control of their 
careers and enhance their employability in order to create more opportunities with other organizations (De Cuyper et al., 2011a).

The measurement of particular aspects of perceived employability results in more successful prediction of turnover than other job- and organization-specific factors (Barrick \& Zimmerman, 2009). This implies that even though other factors are important for successful employee selection, hiring employees who have a positive outlook on their abilities to work successfully is a key construct to measure first and foremost. It must be additionally noted that perceived employability should not be thought of as a facet of cognitive ability. These two concepts are distinct from each other and little evidence has been found in the prediction of turnover based on intelligence (Griffeth et al., 2000).

In their meta-analysis, Griffeth and colleagues (2000) noted that although there is evidence to support the direct relation between perceived employability and turnover, many of the studies report only modest effects (possibly due to other moderating effects). They additionally reported that moderators of the turnover process are important to examine. Most importantly, Holtom and colleagues (2008) stated that over time, employees often become more socialized and embedded in the organization. This provides coping and buffering for shocks that would normally cause turnover.

\section{Job Embeddedness as a Moderator in the Relation between Perceived Employability and Voluntary Turnover}

As employees adapt to the shifting nature of the workforce, being employable is increasingly important. However, being highly employable lowers the felt obligation to and loyalty toward the organization. This will instigate thoughts of leaving and moving on to other opportunities, regardless of whether they are currently planning on leaving 
(De Cuyper et al., 2011a). Ghiselli (1974) specifically reported that those employees who constantly job-hop are more likely to leave their current position and organization. Although there are many predictors of turnover rate, the feelings of attachment and belongingness that make up job embeddedness have been brought forward in the literature (Barrick \& Zimmerman, 2009). Given the propensity of employees with high perceived employability to consider other job opportunities, finding ways to decrease these considerations and increase the retention of successful employees based on how greatly they are attached to an organization can be key. With high job satisfaction being shown to ingrain and embed employees in the organizations (De Cuyper, et al., 2011a), employees high in perceived employability tend to forgo considerations of leaving. Furthermore, a sense of belonging can create ties to the organization, and thus, employees who have this motive to stay are much less likely to turnover (Richer et al., 2002; Schaufeli \& Bakker, 2004). This relation was also shown explicitly by Boswell and colleagues (2008), in which those employees who held more senior positions had a stronger negative relation between organizational commitment and turnover. Holtom and colleagues (2008) found similar results while controlling for many other variables such as job satisfaction and gender. Most important is the finding that job embeddedness was found to be highest in employees who chose to remain in the organization even after shocks that typically are able to induce turnover (Holtom et al., 2008). These shocks were explained to be jarring environmental events that activate psychological analyses that lead to thoughts of quitting. Going beyond job dissatisfaction, shocks such as denial of a promotion are strong and difficult to prepare for; however, job embeddedness was found to aid in this preparation (Holtom et al., 2008). This was true across diverse 
populations of employees, providing strong evidence that job embeddedness is a potential buffer in the perceived employability-turnover relation.

Job embeddedness has been shown to bolster effectively the prediction of turnover above and beyond what perceived employability is able to provide (Boswell et al., 2008) across demographic variables (Holtom et al., 2008). Job embeddedness has also been shown to be a strong moderator in many relations when attempting to better predict candidates' levels of turnover risk. Barrick and Zimmerman (2009) discussed that the links employees make with coworkers and jobs as well as their views of how well they "fit" within the organization as a whole influences the embeddedness of the employees within their organizations. Job embeddedness can be considered a potential buffer in the perceived employability-turnover relation by decreasing job-hopping behaviors. They additionally reported that higher job embeddedness and more contact with the organization helps employees self-select more effectively. By having better contact with the organization, employees are better at choosing positions that are best suited to them. In all, this would help them find a better fit and thus help them stay in that position longer (Barrick \& Zimmerman, 2009).

From a more theoretical perspective, Siegrist (1996) argued for job embeddedness being a moderator in the perceived employability-turnover relation. His Effort-Reward Imbalance Model is based on the knowledge that "effort at work is spent as part of a socially organized exchange process to which society at large contributes in terms of rewards" (p. 29). This model becomes relevant when there is a lack of reciprocity between the employee and the organization. More detailed, effort-reward imbalance occurs when the rewards and resources provided by the organization are less than the 
employee's effort to the organization (De Cuyper et al., 2011a). When this happens, the employee is more likely to become strained (Siegrist, 1996) and is thus more likely to turnover due to the job tension felt, as explained by the Cusp Catastrophe Model of employee turnover (Sheridan \& Abelson, 1983).

Using the unfolding model of turnover, both of these models can be brought together using its explanation of shock-induced leaving. As Holtom and colleagues (2008) explained, employees who did not turnover were found to have the highest levels of job embeddedness, followed by shock-induced leavers. The lowest levels of job embeddedness were found in those who left without any shocks indicating that job embeddedness plays a buffering role in the prediction of turnover. Specifically, it can buffer the relation between perceived employability and turnover when looking at the changing nature of the current workforce (De Cuyper et al., 2011a). The constant changes bring about feelings of job insecurity, and employees react by learning to manage their careers more independently and becoming more employable, thus making them more likely to turnover. However, if the organization were to provide protection from the strain of losing one's job and from potential shocks that can cause turnover, the effects of perceived employability on turnover will diminish, regardless of whether perceived employability is high or low.

In summary, the organization can minimize job tension (Sheridan \& Abelson, 1983) and job insecurity (De Cuyper et al., 2011a) by reducing the effort-reward imbalance (Siegrist, 1996). When this imbalance is reduced, an employee is more likely to give effort back to the organization and feel a greater amount of job embeddedness (in the form of commitment to the organization). This bolstering of job embeddedness then 
makes them more resistant to the shocks of turnover (Holtom et al., 2008). In relation to the purpose of my study, job embeddedness was proposed to buffer the relation between perceived employability and turnover. Employees are less likely to feel the need to look for outside opportunities because they are being adequately rewarded for their work, thus raising their job embeddedness (e.g. commitment) towards the organization. In all, when job embeddedness is high, effects in the turnover relation between perceived employability and voluntary turnover are buffered.

\section{Perceived Organizational Support as a Moderator in the Relation between Perceived Employability and Voluntary Turnover}

Stemming from the Job Demands-Resources Model, job resources (e.g. support from the organization, having job autonomy, given significant tasks, etc.) have been a particularly important dynamic in achieving goals, reducing stress, and motivating personal growth among employees (Bakker \& Demerouti, 2007). The expectation that personal resources match the resources provided by the organization is mirrored by the employee's need for an input-output balance (De Cuyper et al., 2011a). This balance is well evidenced within social exchange theories (Siegrist, 1996), psychological contract research (Dabos \& Rousseau, 2004), and person-environment fit (Greguras \& Diefendorff, 2009). Highly employable workers provide their set of knowledge, skills, and abilities to the organization, which is their input of personal resources. In turn, they carry the expectation that they will be rewarded, which is the output or job resources.

These resources have also been found to be closely tied to the desirability to move. De Cuyper et al. (2011a) found that weak job resources (including organizational support) strengthened the negative relation between perceived employability and turnover 
intentions (tied to the desirability to move as aforementioned). Highly employable workers require a necessary balance between job resources (e.g. organizational support) and personal resources (e.g. relevant knowledge, skills, and abilities) because they know they are providing a lot to the organization and require an adequate reward in return. Workers low in employability will then put less emphasis on job resources because they perceive themselves as offering fewer of their own resources (De Cuyper et al., 2011a).

De Cuyper and colleagues' work (2011a) in particular has been a major impetus for this thesis because there needs to be an ability to discern between the factors of specific job resources. Having a singular category of "resources" which can include autonomy and organizational support is too general. Additionally, DeConinck and Johnson (2009) explicitly stated that perceived organizational support does not play a direct role in the turnover process, but rather one that is a boundary condition. This is corroborated by evidence from Rhoades, Eisenberger, and Armeli (2001), in which indirect effects were found for perceived organizational support in the relation between affective commitment and turnover. However, when examining perceived employability, De Cuyper et al. (2011a) stated that perceived employability was not significantly related to turnover intentions over multiple time periods. They went on to discuss that the weak correlations found were most likely due to an incomplete relation between perceived employability and turnover and explicitly stated "it could be important to account for possible moderators" (p. 260). Moderators were discussed in De Cuyper and colleague's study (2011a), in particular social support from colleagues, and it was found that the relation between perceived employability and turnover intentions was strong when job resources (e.g. social support) were low and conversely found that there was a non- 
significant relation when job resources were high. Additionally, when low support was found from supervisors, perceived employability moderated the relation making it stronger when perceived ease of movement was less (Holtom et al., 2008). In general, it was postulated that perceived employability and perceived organizational support can interact in a moderated fashion to affect turnover.

While researchers parse out many different types of organizational support, a meta-analysis by Rhoades and Eisenberger (2002) found that these studies, which included various types of support such as supervisor support, can be generalized to perceived organizational support, a broader variable. This consolidation is possible because those supervisors who provide and display that support are seen as organizational agents that represent the attitudes of the organization itself. Additionally, when an individual is assessing the support that the organization provides, they take into account all the individuals around them, rather than just one person. I have aimed to further this research by looking at the more generalized perceived organizational support in an effort to extend the current literature. De Cuyper and colleagues (2011a) stated that both support from supervisors as well as fellow employees yielded similar results to those found by Eisenberger and colleagues (2002). This evidence supports research done by Cross and Travaglione (2004) who postulated that those who stay with an organization are more likely to have higher perceived organizational support as well as higher perceived employability. These findings prompted me to research perceived organizational support as a moderator of the relationship between perceived employability and turnover because of a paucity of research between these variables. 
Using an applied perspective, organizations may be able to retain highly employable workers if they provide job resources such as organizational support (De Cuyper et al., 2011a). Evidence for this was found showing that employees were less likely to quit when they were more satisfied with organizational support, even when their employability was high (Holtom et al., 2008). This would not only save enormous amounts of money by lowering turnover, but would also indirectly provide the organization more money because they are retaining the main "money-makers." This research has the potential to resolve the paradox faced by managers throughout the workplace and emphasized in this paper, that hiring preferred, employable workers and fostering employability will pose a danger of increased turnover (Viney, Adamson, \& Doherty, 1997). Focusing on other moderators can thus potentially alter this relation and negate the paradox.

\section{Hypotheses}

The first hypothesis attempts to support the literature that has shown that higher perceived employability is positively related to higher turnover rates.

Hypothesis One: The level of perceived employability will relate positively to voluntary turnover rate.

The second and third hypotheses attempt to address the paucity of research where perceived organizational support and job embeddedness are treated as moderators in the perceived employability-voluntary turnover gap. These hypotheses are focused on showing how both variables strengthen the perceived employability-turnover relation. 
Hypothesis Two: Job embeddedness will moderate the relation between perceived employability and voluntary turnover such that the relation is weaker when the level of job embeddedness is higher.

Hypothesis Three: Perceived organizational support will moderate the relation between perceived employability and voluntary turnover such that the relation is weaker when the level of perceived organizational support is higher. 


\section{CHAPTER III \\ RESEARCH DESIGN}

Method

\section{Participants}

The current study included archival data from 230 participants at a similar job level from a multinational organization. Participants reported their employability at Time 1 and completed a survey containing the attitudinal variables (job embeddedness and perceived organizational support) at Time 2 (three months after Time 1). Approximately one year after Time 1 turnover data was collected from organizational records. Participation was voluntary and anonymous.

\section{Measures}

Perceived Employability. Perceived employability was measured using three items from a scale proposed by Janssens, Sels, and Van den Brande (2003). Each item is measured using a six-point Likert scale with the items being: "I'm confident that I would find another job if I started searching," "It will be difficult for me to find new employment when leaving the organization" (reversed scored), and "In case I'm dismissed, I'll immediately find a job of equal value." With a sample of 1,106 participants, Janssens and colleagues (2003) reported a Cronbach's alpha of .80. Wittekind, Raeder, and Grote (2010) used this scale in a longitudinal study with data measured at three points in time and reported 
Cronbach's alpha ranging between .80 and .88 and test-retest correlations between .73

and .82. Cronbach's alpha for the present study was found to be consistent with Wittekind and colleagues' (2010) range at .86.

Job Embeddedness. Job embeddedness was measured using the seven-item scale developed by Crossley and colleagues (2007). Each item was measured using a sixpoint Likert scale with items such as "It would be difficult for me to leave this organization." With a sample of 306 participants, these authors found a Cronbach's alpha of .88. Furthermore, Ng and Feldman (2010) found reliability for this measure as strong as .94. As for the validity of this measure, Crossley and colleagues (2007) used correlational and reliability analyses to provide evidence for adequate convergent validity. Also, using principle factor analysis to provide discriminant validity, strong job embeddedness factor loadings were found to load on the global job embeddedness factor. This provided unique variance when compared to other organizational commitment and intent to quit factors (which are often misconstrued as being a part of job embeddedness construct definitions). Lastly, Crossley and colleagues (2007) integrated their job embeddedness construct measure into a traditional voluntary turnover model. Using path analysis they confirmed their previous validity and reliability findings. In the current study, Cronbach's alpha was found to be consistent with past findings at .92.

Perceived Organizational Support. Perceived organizational support was measured using six items from the short form of the Survey of Perceived Organizational Support (Items 1, 4, 9, 20, 23, and 27). These items had factor loadings from .71 to .84 (Eisenberg et al., 1986). As for the survey as a whole, Eisenberger and colleagues (1986) conducted two studies on the reliability of their measure and found the Cronbach's alpha 
coefficients to be .97 and .93 (with a sample of 361 and 97 participants respectively). Using exploratory (Eisenberger et al., 1986) and confirmatory factor analysis (Shore \& Tetrick, 1991), strong convergent and discriminant construct validity was found. While these statistics describe the original Survey of Perceived Organizational Support, numerous studies have found strong effects when administering shortened forms of the Survey of Perceived Organizational Support (e.g. Bishop, Scott, \& Burroughs, 2000; Eisenberger et al., 1986; Eisenberger et al., 1990; Rhoades et al., 2001).

In the last two decades, the six-item short form of the Survey of Perceived Organizational Support has been used in the perceived organizational support literature and reliability estimates provide strong evidence for its effectiveness yielding Cronbach's alpha coefficients across samples, languages, and occupations as high as .93 (Loi, Ngo, \& Foley, 2006), .83, and .90 (Eder \& Eisenberger, 2008). Additionally, Loi and colleagues (2006) found evidence of strong validity when conducting further regression and confirmatory factor analyses. In the present study, Cronbach's alpha was found to be strong at .92 .

Voluntary Turnover. Approximately one year after measuring the attitudinal variables, data on voluntary turnover was collected from organizational records. Turnover was coded as $0=$ stayers $(n=203)$ and $1=$ leavers $(n=27)$. 


\section{CHAPTER IV}

\section{ANALYSES AND RESULTS}

The correlations and descriptive statistics between the variables can be found in Table 1. The relation between perceived employability and voluntary turnover in Hypothesis One was tested using a zero-order correlation. The moderation effects of job embeddedness and perceived organizational support on the relation between perceived employability and voluntary turnover were tested individually using moderated binary logistic regression. For the moderated binary logistic regression analyses, the variables in the interaction terms were not centered, as it is not necessary to do so when trying to form accurate interpretations (Hayes \& Matthes, 2009). While tenure, gender, and age were entered into the regression analyses, the resulting statistics did not significantly affect the analyses and thus were not included in the results and interpretation. Additionally, a three-way interaction was investigated between perceived employability, job embeddedness, and perceived organization. There was no evidence of a significant threeway interaction effect in predicting turnover. Thus, to maintain parsimony, is not included in the following results, tables, and figures, $\left(\Delta \chi^{2}[1]=2.67, p>.10\right)$. 
Table 1

Reliabilities, Means, Standard Deviations, and Intercorrelations

\begin{tabular}{lccccccc}
\hline \multicolumn{1}{c}{ Variable } & $\alpha$ & $M$ & $S D$ & 1 & 2 & 3 & 4 \\
\hline 1. Voluntary turnover & - & .12 & .32 & - & & \\
2. Perceived employability & .86 & 9.17 & 4.00 & $.15^{*}$ & - & \\
3. Job embeddedness & .92 & 27.07 & 5.25 & $-.20^{* *}$ & .02 & - \\
4. Perceived organizational & .92 & 18.55 & 6.48 & -.05 & .01 & $.60^{* *}$ & - \\
support & & & & & & & \\
\hline
\end{tabular}

Note. $N=230$ for voluntary turnover and job embeddedness. $N=229$ for perceived employability. $N=227$ for perceived organizational support. For voluntary turnover, $0=$ stayers, 1 = leavers. For perceived employability, scores ranged from $3-18$. For job embeddedness, scores ranged from 9 - 42. For perceived organizational support, scores ranged from $6-36{ }^{*} p<.01 . * * p<.001$.

As Table 1 shows, Hypothesis One was supported as perceived employability was significantly positively related to voluntary turnover, $r(229)=.15, p=.03$.

For Hypothesis Two, moderated logistic regression was used because the criterion variable of voluntary turnover is dichotomous. For this hypothesis, job embeddedness was examined as a moderator on the relation between perceived employability and voluntary turnover such that the relation between percieved employability and turnover would be weaker and potentially become negative with stronger job embeddedness. In the first step, perceived employability and job embeddedness were entered into the regression model. In the second step, the interaction term created by multiplying 
perceived employability and job embeddedness was entered into the regression model. Because it is necessary to use logistic regression, measures of deviance must be used rather than the sums of squares, as normally seen in ordinary least squares regression (Cohen, Cohen, West, \& Aiken, 2003). Table 2 displays the deviance or the log likelihood $(-2 L L)$ between one model and another model with added predictors. Measuring the deviance allows us to distinguish the "badness of fit" and the model with a greater deviance is considered the worse model (Cohen et al., 2003). If the log likelihood in a less complete model (such as in Block 1 of Table 2) is significantly greater than that of a more complete model (such as in Block 2 of Table 2), the more complete model is said to significantly contribute to the prediction of the criterion variable. This can be found in Table 2 in that Block $0(-2 L L=166.13)$ and Block $1(-2 L L=153.37)$ have a greater log likelihood than that in Block $2(-2 L L=136.30)$. Therefore, when the interaction term was added, the deviance was at its lowest and significant predictiveness contributed to the voluntary turnover.

In Table 3, the odds ratio $(\operatorname{Exp} B)$ provides further evidence in discovering the predictiveness of adding in an interaction term. An odds ratio is used to represent the coefficients for predictors in a logistic regression model and are able to signify "by what amount the odds of being in the case group are multiplied when the predictor is incremented by a value of one unit" (Cohen et al., 2003, p. 492). In the case of the current model, an odds ratio that is less than 1.0 corresponds with a $B$ coefficient that is negative. Table 3 shows this when referring to the introduction of the interaction term. While perceived employability and job embeddedness individually have an odds ratio greater than $1.0(\operatorname{Exp} B=2.81$ and $\operatorname{Exp} B=1.36$, respectively $)$, the interaction of perceived 
employability and job embeddedness has a significant odds ratio less than $1.0(\operatorname{Exp} B=$ $.96)$.

When aggregating the results in Table 2 and Table 3, Hypothesis Two was supported in that the interaction between perceived employability and job embeddedness significantly negatively related to turnover following the entering of the control and main effect variables, $\Delta \chi^{2}(1)=17.07, p<.001$. Due to the nature of logistic regression, Nagelkerke's pseudo $R^{2}$ was used to investigate the proportional improvement between the control variables and the full model (Kraimer, Seibert, Wayne, Liden, \& Bravo, 2011). The results pointed to a $13.2 \%$ improvement when comparing the first step (main effects) to the second step (full model with added interaction term). 
Table 2

Moderated Logistic Regression Analysis Results Predicting Voluntary Turnover From Perceived Employability, Job Embeddedness, and the Perceived Employability by Job Embeddedness Interaction (A)

Difference from Nagelkerke

Model Total Previous Block $\quad R^{2}$

\begin{tabular}{lllllll}
\hline Block & Predictor Variable & $-2 \mathrm{LL}$ & $\mathrm{df}$ & $-2 \mathrm{LL}$ & $\mathrm{df}$ & \\
\hline 0 & Intercept & 166.13 & 0 & & & \\
1 & & & & & & \\
& & & & & & \\
& & & & & & \\
& job embeived employability, & 153.37 & 2 & $12.76^{*}$ & 2 & .24 \\
& Perceived employability & 136.30 & 3 & $17.07^{* *}$ & 1 & \\
& by job embeddedness & & & & &
\end{tabular}

Note. $N=229 .{ }^{*} p<.01 .{ }^{*} p<<.001 \mathrm{LL}=\log$ likelihood 
Table 3

Moderated Logistic Regression Analysis Results Predicting Voluntary Turnover From Perceived Employability, Job Embeddedness, and the Perceived Employability by Job Embeddedness Interaction (B)

\begin{tabular}{|c|c|c|c|c|}
\hline Block & Predictor Variable & $B$ & SE $B$ & $\operatorname{Exp}(B)$ \\
\hline 0 & Intercept & $-2.01 * *$ & .21 & .13 \\
\hline \multirow[t]{2}{*}{1} & Perceived employability & .10 & .05 & 1.11 \\
\hline & Job Embeddedness & $-.10^{*}$ & .04 & .90 \\
\hline \multirow[t]{4}{*}{2} & Perceived employability & $1.03 * *$ & .26 & 2.81 \\
\hline & Job Embeddedness & $.31^{*}$ & .11 & 1.36 \\
\hline & Perceived employability by job & $-.04 * *$ & .01 & .96 \\
\hline & embeddedness & & & \\
\hline
\end{tabular}

Note. $N=229 . B=\log$ odds; $\mathrm{SE} B=$ standard error of $\log$ odds; $\operatorname{Exp}(B)=$ odds ratio. $p<.05, * p<.01, * * p<.001$.

The significant interaction between perceived employability and job embeddedness is further displayed in Figure 1. The unstandardized regression coefficients were plotted to show the probability of turnover as a function of perceived employability about the mean of job embeddedness. One standard deviation above the mean and one standard deviation below the mean were used around the mean to display high and low job embeddedness, respectively. Figure 1 shows that as an employee's 
perceived employability increases, those who have low job embeddedness have a higher probability of turning over. However, if the employee has high job embeddedness, he or she has a lower probability of turning over and, in fact, the probability decreases as perceived employability increases.

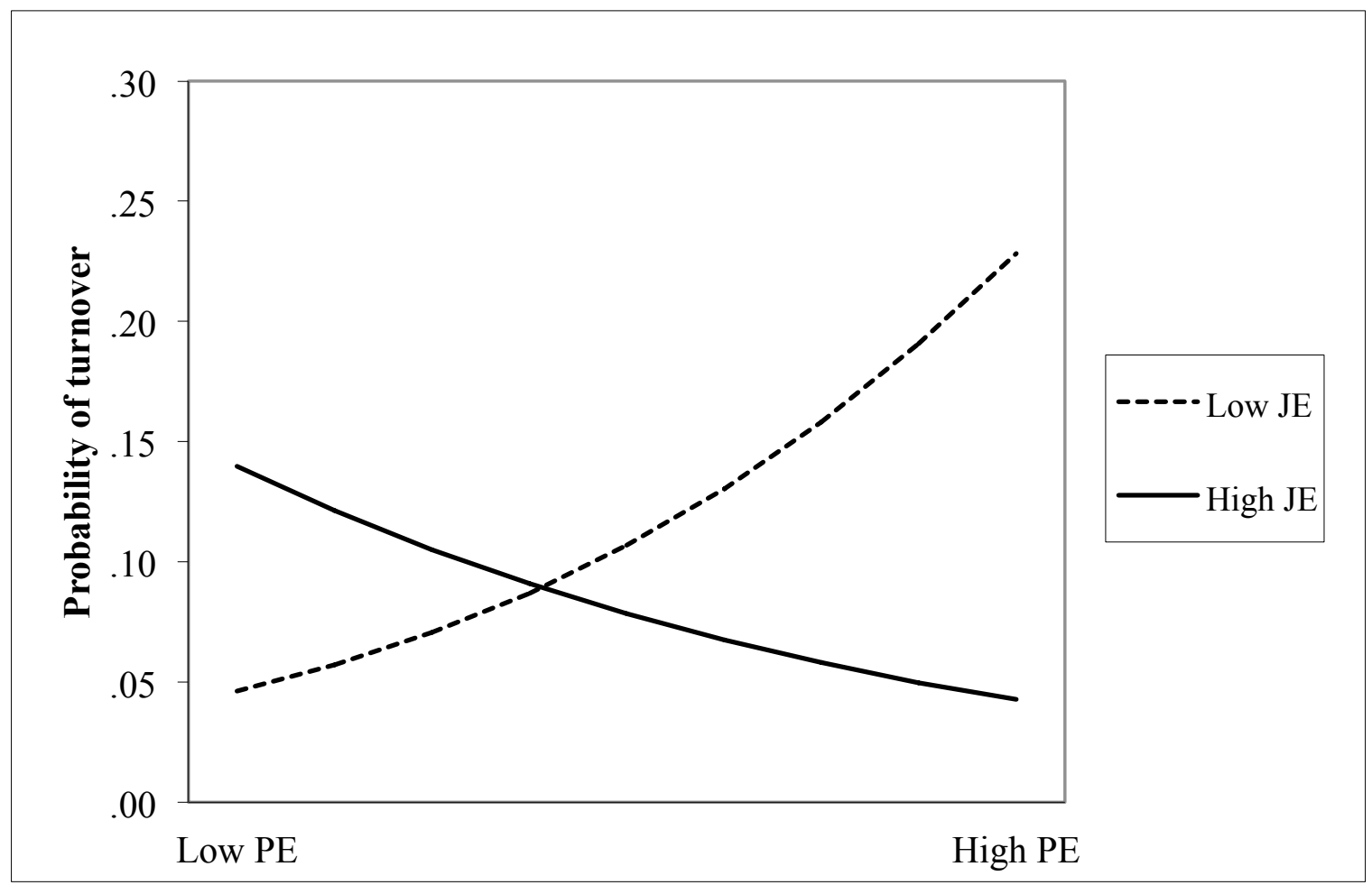

Figure 1. Plot of Two-way Logistic Interaction between Perceived Employability and Job Embeddedness

Note. $\mathrm{PE}=$ perceived employability. $\mathrm{JE}=$ job embeddedness

For Hypothesis Three, moderated logistic regression was used again because the criterion variable of voluntary turnover is dichotomous. For this hypothesis, perceived organizational support was examined as a moderator on the relation between perceived employability and voluntary turnover such that the relation between percieved employability and turnover would be weaker and potentially become negative with stronger perceived organizational support. In the first step, perceived employability and 
perceived organizational support were entered into the regression model. In the second step, the interaction term found between perceived employability and perceived organizational support was entered into the regression model. Again, because we have to use logistic regression, measures of deviance must be used rather than the sums of squares, as normally seen in ordinary least squares regression (Cohen et al., 2003). Table 4 displays the deviance or the log likelihood $(-2 L L)$ between one model and another model with added predictors. Measuring the deviance allows us to distinguish the "badness of fit" and the model with a greater deviance is considered the worse model (Cohen et al., 2003). If the log likelihood in a less complete model (such as in Block 1 of Table 2) is significantly greater than that of a more complete model (such as in Block 2 of Table 2), the more complete model is said to significantly contribute to the prediction of the criterion variable. This can be found in Table 4 in that Block $0(-2 L L=165.37)$ and Block $1(-2 L L=160.14)$ have a greater log likelihood than that in Block $2(-2 L L=$ 151.75). Therefore, when the interaction term was added, the deviance was at its lowest and significant predictiveness was found to contribute to the voluntary turnover.

In Table 5, the odds ratio $(\operatorname{Exp} B)$, again, provides further evidence in discovering the predictiveness of adding in an interaction term. In the case of the current model, an odds ratio that is less than 1.0 corresponds with a $B$ coefficient that is negative. Table 5 shows this when referring to the introduction of the interaction term. While perceived employability and job embeddedness individually have an odds ratio greater than 1.0 $(\operatorname{Exp} B=1.62$ and $\operatorname{Exp} B=1.23$, respectively), the interaction of perceived employability and perceived organizational support has a significant odds ratio less than $1.0(\operatorname{Exp} B=$ $.98)$. 
When aggregating the results in Table 4 and Table 5, Hypothesis Three was supported in that the interaction between perceived employability and perceived organizational support significantly negatively related to turnover after entering the control and main effect variables, $\Delta \chi^{2}(1)=8.39, p=.004$. Due to the nature of logistic regression, Nagelkerke's pseudo $R^{2}$ was used to investigate the proportional improvement between the control variables and the full model (Kraimer, Seibert, Wayne, Liden, \& Bravo, 2011). The results pointed to a $6.9 \%$ improvement when comparing the first step (main effects) to the second step (full model with added interaction term). 
Table 4

Moderated Logistic Regression Analysis Results Predicting Voluntary Turnover From Perceived Employability, Perceived Organizational Support, and the Perceived Employability by Perceived Organizational Support Interaction (A)

Difference from

Model Total Previous Block

Nagelkerke

$R^{2}$

\begin{tabular}{llllll}
\hline Block & Predictor Variable & $-2 \mathrm{LL}$ & $\mathrm{df}$ & $-2 \mathrm{LL}$ & $\mathrm{df}$
\end{tabular}

\begin{tabular}{llll}
\hline 0 & Intercept & 165.37 & 0
\end{tabular}

1 Perceived employability,

perceived organizational $160.14 \quad 2 \quad 5.23 * \quad 2$

.04

support

2 Perceived employability

by perceived

$\begin{array}{llll}151.75 & 3 & 8.39 * * & 1\end{array}$

.11

organizational support

Note. $N=229 .{ }^{*} p<.10 .{ }^{* *} p<.01 \mathrm{LL}=\log$ likelihood 
Table 5

Moderated Logistic Regression Analysis Results Predicting Voluntary Turnover From Perceived Employability, Perceived Organizational Support, and the Perceived Employability by Perceived Organizational Support Interaction (B)

\begin{tabular}{|c|c|c|c|c|}
\hline Block & Predictor Variable & $B$ & $\mathrm{SE} B$ & $\operatorname{Exp}(B)$ \\
\hline 0 & Intercept & $-2.00 * *$ & .21 & .43 \\
\hline 1 & Perceived employability & .11 & .05 & 1.11 \\
\hline & Perceived organizational support & -.03 & .03 & .97 \\
\hline 2 & Perceived employability & $.48^{*}$ & .15 & 1.62 \\
\hline & Perceived organizational support & .21 & .09 & 1.23 \\
\hline & $\begin{array}{l}\text { Perceived employability by perceived } \\
\text { organizational support }\end{array}$ & $-.02 *$ & .01 & .98 \\
\hline
\end{tabular}

Note. $N=229 . B=\log$ odds; $\operatorname{SE} B=$ standard error of $\log$ odds; $\operatorname{Exp}(B)=$ odds ratio. $p<.05, * p<.01, * * p<.001$.

The significant interaction between perceived employability and perceived organizational support is further displayed in Figure 2. The unstandardized regression coefficients were plotted to show the probability of turnover as a function of perceived employability about the mean of perceived organizational support. One standard deviation above the mean and one standard deviation below the mean were used around 
the mean to display high and low perceived organizational support, respectively. Figure 2 shows that as an employee's perceived employability increases, those who have low perceived organizational support have a higher probability of turning over. However, if the employee has high perceived organizational support, he or she has a lower probability of turning over and, in fact, the probability decreases as perceived employability increases.

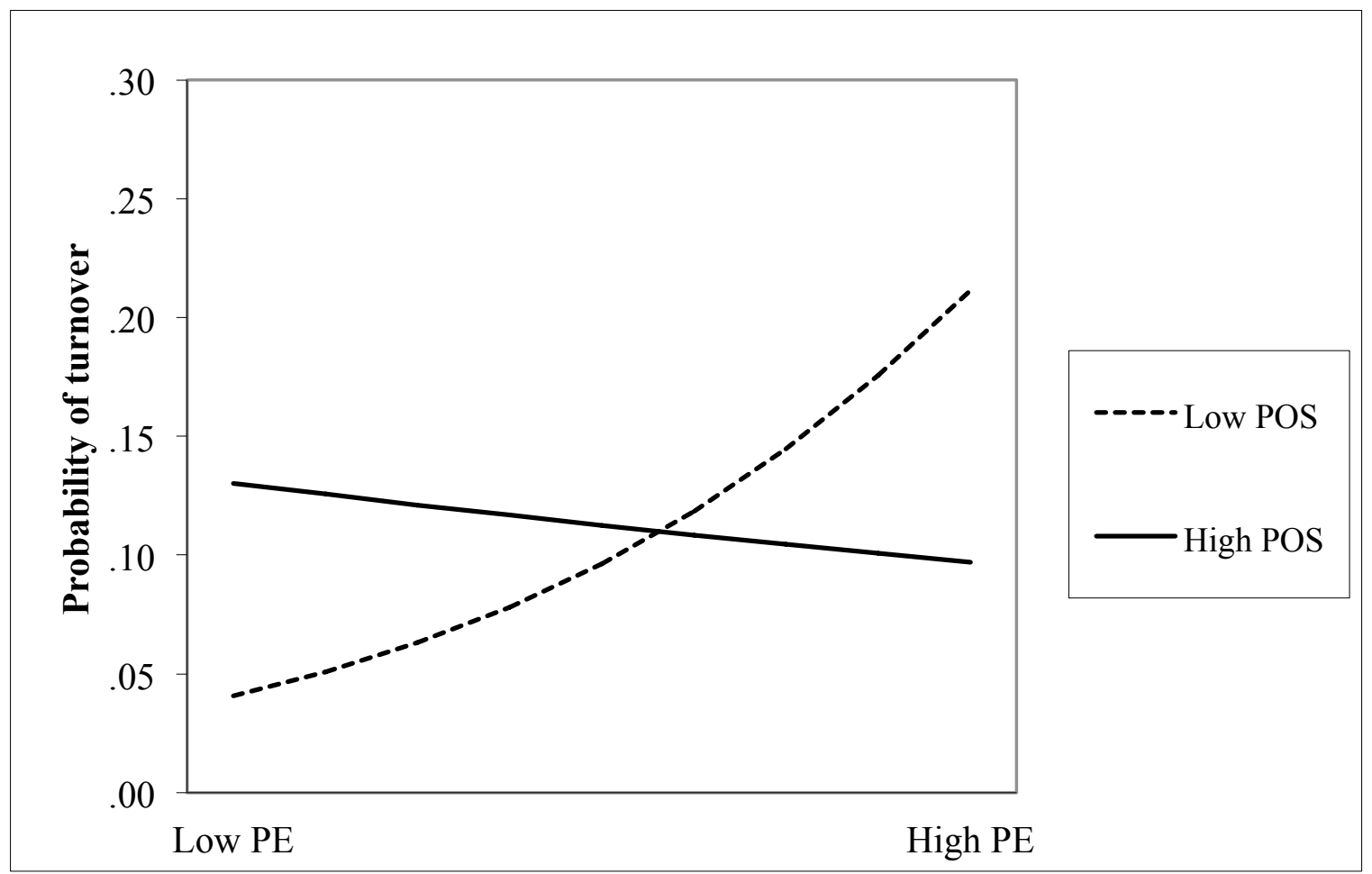

Figure 2. Plot of Two-way Logistic Interaction between Perceived Employability and Perceived Organizational Support

Note. $\mathrm{PE}=$ perceived employability. $\mathrm{POS}=$ perceived organizational support 


\section{CHAPTER V \\ DISCUSSION \\ Summary of Findings}

This study first examined the main effect between perceived employability and voluntary turnover. Results supported all three hypotheses. It was hypothesized that the higher an individuals' perceived employability, the higher the chance of the individual turning over (Hypothesis One). Historically, perceived employability has been found to be positively related to turnover (De Cuyper et al., 2011a), but has been limited by the use of turnover intentions rather than actual turnover data. This study improves upon previous studies by using actual turnover archival data while finding the same trend of results.

Next, it was hypothesized that job embeddedness would moderate the relation between percieved employability and turnover in that the relation would be weaker and potentially negative with stronger job embeddedness. Testing this yielded significant results, but since binary logistic regression does not adhere to the standard interpretation of ordinary least squares regression analyses, the log likelihood $(-2 L L)$, the odds ratio $(\operatorname{Exp}[B])$, and a pseudo $R^{2}$ were used to find these outcomes. As seen in Table 2 and Table 3, the log likelihood and the odds ratio for percieved employability and job embeddedness indicated a positive effect. However, upon investigation of the interaction term, these statistics indicated a negative effect. Given the positive to negative effect 
switch after the introduction of the interaction term and a significant p-value for both statistics, the findings indicate that job embeddedness has a significant moderation effect on the relation between perceived employability and voluntary turnover such that when added into the model, turnover decreases as the interaction between perceived employability and job embeddedness increases. This is in contrast to the finding in Hypothesis One that as perceived employability increases, so does voluntary turnover. This finding suggests that as long as an employee is strongly embedded, he or she will not want to voluntarily turn over even when aware that he or she has the ability to move on to other opportunities. This result would seem logical because an employee may find that a comfortable environment (on and off the job) outweighs the desire to move to another job, possibly adding stress and jeopardizing the positive situation that he or she is in currently.

The moderating effects that are found regarding Hypothesis Three when introducing perceived organizational support in the perceived employability-turnover relation yield similar significant results to that of job embeddedness. As seen in Table 4 and Table 5, the log likelihood and the odds ratio for percieved employability and perceived organizational support indicated a positive effect. However, upon investigation of the interaction term, these statistics indicated a negative effect. Given the positive to negative effect switch after the introduction of the interaction term and a significant pvalue for both statistics, the findings indicate that perceived organizational support has a significant moderation effect on the relation between perceived employability and voluntary turnover such that when added into the model, turnover decreases as the interaction between perceived employability and perceived organizational support 
increases. This, again, is in contrast to the finding in Hypothesis One that as perceived employability increases, so does voluntary turnover. The moderating effects that are found when introducing perceived organizational support in the perceived employabilityturnover relation yield similar significant results to that of job embeddedness. This leads to the idea that as long as an employee perceives high organizational support, he or she will not want to voluntarily turn over even when aware that he or she has the ability to move on to other opportunities. Again, this would seem logical because an employee may find that a supportive organizational environment outweighs the desire to move on to another job, again possibly adding stress and disruption to the current environment.

One important consideration to take into account, either as a limitation or possibly for future research is the correlation between the two moderators, job embeddedness and perceived organizational support. These variables could have synergistic effects on each other and further research would be necessary to find these. This and other considerations are made in the following sections.

\section{Theoretical and Practical Implications}

While the strength of perceived employability is indicative of turning over, the moderating effects that job embeddedness and perceived organizational support buffer the employability-turnover relation significantly. Simply put, the desire to leave becomes less even when perceived employability increases as long as there are these moderators present in higher levels. This finding is useful from an organizational perspective because an organization can select employees that score high in areas of job embeddedness and perceived organizational support, leading to less organizational stress and greater benefit from valuable employees (Van der Heijde \& Van der Heijden, 2006). 
While the measures used in this study were obtained while the employees were currently employed, variations of these could be used as predictive measures for individuals who are in the hiring process. Those who score higher in job embeddedness and perceived organizational support would be more valuable to the organization because voluntary turnover, which can be a financial burden, would be less likely. Also, the organization could hire more qualified employees with less fear that they will move to another opportunity shortly after being hired.

Another important implication that this study helps to solidify is De Cuyper and colleagues' (2011a) conclusion that perceived employability may not directly cause turnover, but rather many intervening variables can change and reduce the strength of the relation between the two variables. This implication has the potential for future research in other moderating variables that may be more predictive during the hiring process.

\section{Limitations}

The first source of limitations comes from the criterion variable of voluntary turnover. The inherent nature of turnover is not as dichotomous as this study, as well as many other studies portray. While the binary option of whether the individual stayed or left is most often used, the motivations behind such actions are difficult to account for. For example, a participant that is having family issues may be forced to leave their position even if they did not want or intend to. This would potentially skew results and overestimate the quantity of those who actually wanted to leave their position. Voluntary turnover adds additional caveats into the problem of collecting accurate turnover data. One example would be, an individual may not have intentions of leaving, but do so because they overhear they are going to be fired. This can go both ways if they are fired 
for wanting to leave or for seeking out other positions while in their current position. This will either overestimate or underestimate the actual number of leavers in the end result.

Another source of limitations in this study has to do with the vague nature of the archival data. Further classification of the participants could have added to the discussion of why certain results were reached. The number of participants was also an issue especially when looking at potential results of the three-way interaction. The results found were not significant, but could be seen approaching significance. Greater power could be necessary to further the research on the effects of a three-way interaction between perceived employability, job embeddedness, and perceived organizational support.

Additionally, without knowing the organizational structure nor the job type, it is difficult to determine whether perceived employability would be affected greatly by those higher up or lower down within the organization.

\section{Future Research}

While perceived employability was one of the foci of this study, actual employability would be interesting to study as well. Being able to measure ones actual employability would be very useful to an organization's selection measures.

Additionally, looking into antecedents to employability could also be beneficial in the field. Variables in personality could add important research opportunities as well as contextual variables such as socio-economic status. While someone may be highly employable and thus more likely to turnover, a person high in agreeableness may not leave due to not wanting to burden others. Also, those with low socio-economic status 
may take any job that is offered even if they are highly employable and have many more opportunities than they think they do.

Upon compiling the literature review, the concept of succession planning came up numerous times. Extending the present study's findings in more practical applications, such as management planning, would be intriguing. It is crucial that managers be prepared for their role in leading part, if not all, of an organization.

Mintzberg (1989) expresses his disdain for the existing trend of management selection and how prepared (or ill prepared) employees seem to be when moving into management roles. While this may be accurate for many organizations, organizations in the 1970s (most prominently General Electric) attempted to combat this trend by using what was known as succession planning (Kesler, 2002). Just as baseball uses the minor league to prepare players for the major league, organizations began using programs to monitor employees' potential to fulfill management and executive positions later in their career. They assessed leadership and management talent (among other characteristics) in order to ascertain who would and who would not be worth preparing for management and executive positions (Kesler, 2002).

Although Mintzberg may agree with this practice, the timing of his book coincided with the fall of widespread use of succession planning, probably a large impetus for his writing Mintzberg On Management. While such planning was flourishing within Fortune 500 companies throughout the 1970s and 1980s, the early 1990s saw succession planning being replaced by more "bureaucratic and procedural-bound" (Kesler, 2002, p. 2) practices. This change likely occurred because the succession planning programs were wrought with difficulty in effectively executing them. It left 
employees puzzled as to how to get into the programs, so the employers had to take time to run the program, and employees had to take time away to participate (Fernández-Aráoz et al., 2011).

However, while planning for employee promotion is still present, it has taken different routes than succession planning and has been more focused on replacementplanning. The key difference is that succession planning (sometimes known as talentpool management) involves creating feeder groups up and down the hierarchy of leadership (Charan, Drotter, \& Noel, 2001). Replacement-planning focuses on recognizing specific "back-up candidates" and leaves much of the assessment of leadership characteristics out, preferring rather to use a position-driven forecast (Kesler, 2002).

While replacement planning is easier, it has not been shown to work as well as succession planning, even though the methods for succession planning have been troubling as well. Few best practices have been solidly established and selection criteria need to be firmly agreed upon (Fernández-Aráoz et al., 2011). I believe that the present study could extend its findings to this practical application in further studies.

Future studies may also benefit from examining the tenure of the individuals. While this study briefly examined this variable, grouping individuals by how long they have been with an organization could potentially lead to future insights into voluntary turnover. The Honeymoon-Hangover Effect is an important concept to take into consideration because the process of voluntarily turning over can develop over time (Boswell et al., 2008; Holtom et al., 2008). Boswell and colleagues (2008) detailed how the time in history is important in distinguishing major attitude changes within 
generations of employees. This could have a major impact on certain moderators that affect the relations between voluntary turnover and its antecedents.

In conclusion, the effects of perceived employability on that of voluntary turnover is consistent with the present literature. Additionally, job embeddedness and perceived organizational support were found to moderate the relation between perceived employability and voluntary turnover in that when both variables increase in strength, the relation between perceived employability and voluntary turnover decreases in strength. Practically, this could potentially lead to predictive measure that take into account job embeddedness and perceived organizational support in finding strong employees that are less likely to leave their current position. 


\section{REFERENCES}

Bakker, A. B., \& Demerouti, E. (2007). The job demands-resources model: State of the art. Journal of Managerial Psychology, 22(3), 309-328.

Barrick, M. R., \& Zimmerman, R. D (2009). Hiring for retention and performance. Human Resource Management, 48(2), 183-206.

Berntson, E., \& Marklund, S. (2007). The relationship between perceived employability and subsequent health. Work and Stress, 21(3), 279-292.

Berntson, E., Sverke, M., \& Marklund, S. (2006). Predicting perceived employability: Human capital or labour market opportunities? Economic and Industrial Democracy, 27(2), 223-244.

Bishop, J. W., Scott, K. D., \& Burroughs, S. M. (2000). Support, commitment, and employee outcomes in a team environment. Journal of Management, 26(6), 1113-1132.

Boswell, W. R., Run Ren, L., \& Hinrichs, A. T. (2008). Voluntary employee turnover: Determinants, processes, and future directions. In J. Barling \& C. L. Cooper (Eds.), The SAGE handbook of organizational behavior (pp. 196-216). Los Angeles; London: SAGE.

Briscoe J. P., \& Hall, D. T. (2006). The interplay of boundaryless and protean careers: Combinations and implications. Journal of Vocational Behavior, 69(1), 4-18.

Buss (2008). Human nature and individual differences. In O. P. John, R. W. Robins, \& L. A. Pervin (Eds.), Handbook of personality: Theory and Research (pp. 47-48). New York: The Guilford Press.

Charan, R., Drotter, S. J., \& Noel, J. L. (2001). The leadership pipeline: How to build the leadership powered company. Retrieved from http://ehis.ebscohost.com.proxy.lib.ilstu.edu/eds/detail?vid=2\&hid=22\&sid=2flb d7e1-014c-4bc0-b260-

5e6e56ed2821\%40sessionmgr14\&bdata $=$ JnNpdGU9ZWRzLWxpdmUmc2NvcG U9c210ZQ\%3d\%3d\#db=edshlc\&AN=edshlc.008572235-9.

Clinton, M., Knight, T., \& Guest, D. E. (2012). Job embeddedness: A new attitudinal measure. International Journal of Selection and Assessment, 20(1), 111-117.

Cohen, J., Cohen, P., West, L. S., \& Aiken, S. G. (2002). Applied multiple regression/correlation analysis for the behavioral sciences. Mahwah, NJ: Erlbaum.

Cross, B., \& Travaglione, A. (2004). The times they are a-changing: Who will stay and who will go in a downsizing organization? Personnel Review, 33(3), 275-290.

Crossley, C. D., Bennett, R. J., Jex, S. M., \& Burnfield, J. L. (2007). Development of a global measure of job embeddedness and integration into a traditional model of voluntary turnover. Journal of Applied Psychology, 92(4), 1031-1042. 
Dabos, G. E., \& Rousseau D. M. (2004). Mutuality and reciprocity in the psychological contracts of employees and employers. Journal of Applied Psychology, 89(1), 5272.

DeConinck, J. B., \& Johnson, J. T. (2009). The effects of perceived supervisor support, perceived organizational support, and organizational justice on turnover among salespeople. Journal of Personal Selling \& Sales Management, 29(4), 333-350.

De Cuyper, N., Mäkikangas, A., Kinnunen, U., Mauno, S., \& De Witte, H. (2012). Cross-lagged associations between perceived external employability, job insecurity, and exhaustion: Testing gain and loss spirals according to the Conservation of Resources Theory. Journal of Organizational Behavior, 33, 770788.

De Cuyper, N., Mauno, S., Kinnunen, U., \&Makikangas, A. (2011). The role of job resources in the relation between perceived employability and turnover intention: A prospective two-sample study. Journal of Vocational Behavior, 78, 253-263.

De Cuyper, N., Raedner, S., Van der Heijden, B. I. J. M., \& Wittekind, A. (2012). The association between workers' employability and burnout in a reorganization context: Longitudinal evidence building upon the conservation of resources theory. Journal of Occupational Health Psychology, 17(2), 162-174.

De Cuyper, N., Van der Heijden, B. I. J. M., \& De Witte, H. (2011). Associations between perceived employability, employee well-being, and its contribution to organizational success: A matter of psychological contracts? The International Journal of Human Resource Management, 22(7), 1486-1503.

Eder, P., \& Eisenberger, R. (2008). Perceived organizational support: Reducing the negative influence of coworker withdrawal behavior. Journal of Management, 34(1), 55-68.

Eisenberger, R., Fasolo, P., \& Davis-LaMastro, V. (1990). Perceived organizational support and employee diligence, commitment, and innovation. Journal of Applied Psychology, 75(1), 51-59.

Eisenberger, R., Huntington, R., Hutchison S., \& Sowa, D. (1986). Perceived organizational support. Journal of Applied Psychology, 71(3), 500-507.

Eisenberger, R., Stinglhamber, F., Vandenberghe, C., Sucharski, I. L. \& Rhoades, L. (2002). Perceived supervisor support: Contributions to perceived organizational support and employee retention. Journal of Applied Psychology, 87(3), 565-573.

Fernández-Aráoz, C., Groysberg, B., \& Nohria, N. (2011). How to hang on to your high potentials. Harvard Business Review, 89(10), 76-83.

Forrier, A., Sels, L., \& Stynen, D. (2009). Career mobility at the intersection between agent and structure: A conceptual model. Journal of Occupational \& Organizational Psychology, 82(4), 739-759.

Gelfand, M. J., Erez, M., \& Aycan, Z. (2007). Cross-cultural organizational behavior. Annual Review of Psychology, 58, 479-514.

Ghiselli, E. E. (1974). Some perspectives for industrial psychology. American Psychologist, 29(2), 80-87.

Glebbeek, A. C., \& Bax, E. H. (2004). Is high employee turnover really harmful? An empirical test using company records. Academy of Management Journal, 47(2), 277-286. 
Greguras, G. J., \& Diefendorff, J. M. (2009). Different fits satisfy different needs: Linking person-environment fit to employee commitment and performance using self-determination theory. Journal of Applied Psychology, 94(2), 465-477.

Griffeth, R. W., Hom, P. W., \& Gaertner, S. (2000). A meta-analysis of antecedents and correlates of employee turnover: Update, moderator tests, and research implications for the next millennium. Journal of Management, 26(3), 463-488.

Hayes, A. F., \& Matthes, J. (2009). Computational procedures for probing interactions in OLS and logistic regression: SPSS and SAS implementations. Behavior Research Methods, 41(3), 924-936.

Hobfoll, S. E. (2001). The influence of culture, community, and the nested-self in the stress process: Advancing conservation of resources theory. Applied Psychology: An International Review, 50(3), 337-421.

Holtom, B. C., Mitchell, T. R., Lee T. W., \& Eberly, M. B. (2008). Turnover and retention research: A glance at the past, a closer review of the present, and a venture into the future. The Academy of Management Annals, 2(1), 231-274.

Ito, J. K., \& Brotheridge, C. M. (2005). Does supporting employees' career adaptability lead to commitment, turnover, or both? Human Resource Management, 44(1), 519.

Jackson, S. E., Schwab, R. L., \& Schuler, R. S. (1986). Toward an understanding of the burnout phenomenon. Journal of Applied Psychology, 71(4), 630-640.

Janssens, M., Sels, L., \& Van den Brande, I. (2003). Multiple types of psychological contracts: A six-cluster solution. Human Relations, 56(11), 1349-1378.

Kesler, G. C. (2002). Why the leadership bench never gets deeper: Ten insights about executive talent development. Human Resource Planning, 24(1), 32-44.

Kraimer, M. L., Seibert, S. E., Wayne, S. J., Liden, R. C., \& Bravo, J. (2011). Antecedents and outcomes of organizational support for development: The critical role of career opportunities. Journal of Applied Psychology, 96(3), 485-500.

Kinnunen, U., Mäkikangas, A., Mauno, S., Siponen, K., \& Nätti, J. (2011). Perceived employability: Investigating outcomes among involuntary and voluntary temporary employees compared to permanent employees. Career Development International, 16(2), 140-160.

Lee, T. W., Mitchell, T. R., Wise, L., \& Firemen, S. (1996). An unfolding model of voluntary employee turnover. Academy of Management Journal, 39(1), 5-36.

Loi, R., Ngo, H., \& Foley, S. (2006). Linking employees' justice perceptions to organizational commitment and intention to leave: The mediating role of perceived organizational support. Journal of Occupational and Organizational Psychology, 79, 101-120.

Maertz, C. P., \& Griffeth, R. W. (2004). Eight motivational forces and voluntary turnover: A theoretical synthesis with implications for research. Journal of Management, 30(5), 667-683.

Maertz, C. P., Stevens, M. J., \& Campion, M. A. (2003). A turnover model for the Mexican maquiladoras. Journal of Vocational Behavior 63, 111-135.

March, J. G., \& Simon, H. A. (1958). Organizations. New York: Wiley.

Meyer, J. P., \& Allen, N. J. (1991). A three-component conceptualization of organizational commitment. Human Resource Management Review, 1(1), 61-89. 
Mintzberg, H. (1989). Mintzberg on management: Inside our strange world of organizations. New York: The Free Press.

Mitchell, T. R., Holtom, B. C., Lee, T. W., Sablynski, C. J., \& Erez, M. (2001). Why people stay: Using job embeddedness to predict voluntary turnover. Academy of Management Journal, 44(6), 1102-1121.

Mobley, W. H. (1977). Intermediate linkages in the relationship between job satisfaction and employee turnover. Journal of Applied Psychology, 62(2), 237-240.

Mobley, W. H., Griffeth, R. W., Hand, H. H., \& Meglino, B. M. (1979). Review and conceptual analysis of the employee turnover process. Psychological Bulletin, 86(3), 493-522.

Mor Barak, M. E., Nissly, J. A., \& Levin, A. (2001). Antecedents to retention and turnover among child welfare, social work, and other human service employees: What can we learn from the past research? A review and metanalysis. Social Service Review, 75(4), 625-661.

Muchinsky, P. M., \& Tuttle, M. L. (1979). Employee turnover: An empirical and methodological assessment. Journal of Vocational Behavior, 14(1), 43-77.

Ng, T. W. H., \& Feldman, D. C. (2010). The effects of organizational embeddedness on development of social capital and human capital. Journal of Applied Psychology, 95(4), 696-712.

Pan, S., \& Yeh, Y. (2012). Impact of value congruence on work-family conflicts: The mediating role of work-related support. Journal of Social Psychology, 152(3), 270-287.

Price, J. L. (1977). The study of turnover. Ames: Iowa State University Press.

Rhoades, L., \& Eisenberger, R. (2002). Perceived organizational support: A review of the literature. Journal of Applied Psychology, 87(4), 698-714.

Rhoades, L., Eisenberger, R., \& Armeli, S. (2001). Affective commitment to the organization: The contribution of perceived organizational support. Journal of Applied Psychology, 86(5), 825-836.

Richer, S. F., Blanchard, C., \& Vallerand, R. J. (2002). A motivational model of work turnover. Journal of Applied Social Psychology, 32(10), 2089-2113).

Rothwell, A., \& Arnold, J. (2007). Self-perceived employability: Development and validation of a scale. Personnel Review, 36(1), 23-41.

Rothwell, A., Jewell, S., \& Hardie, M. (2009). Self-perceived employability: Investigating the responses of post-graduate students. Journal of Vocational Behavior, 75, 152-161.

Schaufeli, W. B., \& Bakker, A. B. (2004). Job demands, job resources, and their relationship with burnout and engagement: A multi-sample study. Journal of Organizational Behavior, 25(3), 293-315.

Settoon, R. P., Bennett N., \& Liden, R. C. (1996). Social exchange in organizations: Perceived organizational support, leader-member exchange, and employee reciprocity. Journal of Applied Psychology, 81(3), 219-227.

Sheridan, J. E., \& Abelson, M. A. (1983). Cusp catastrophe model of employee turnover. Academy of Management Journal, 26(3), 418-436.

Shore, M. L., \& Tetrick, L. E. (1991). A construct validity study of the survey of perceived organizational support. Journal of Applied Psychology, 76(5), 637-643. 
Siegrist, J. (1996). Adverse health effects of high-effort/low-reward conditions. Journal of Occupational Health Psychology, 1(1), 27-41.

Steel, R. P., \& Griffeth, R. W. (1989). The elusive relationship between perceived employment opportunity and turnover behavior: A methodological or conceptual artifact? Journal of Applied Psychology, 74(6), 846-854.

Sullivan, S. E. (1999). The changing nature of careers: A review and research agenda. Journal of Management, 25(3), 457-484.

Tanova, C., \& Holtom, B. C. (2008). Using job embeddedness factors to explain voluntary turnover in four European countries. The International Journal of Human Resource Management, 19(9), 1553-1568.

Van der Heijde, C. M., \& Van der Heijden, B. I. J. M. (2006). A competence-based and multidimensional operationalization and measurement of employability. Human Resource Management, 45(3), 449-476.

Viney, C., Adamson, S., \& Doherty, N. (1997). Paradoxes of fast-track career management. Personnel Review, 26(3), 174-186.

Wittekind, A., Raeder, S., \& Grote, G. (2010). A longitudinal study of determinants of perceived employability. Journal of Organizational Behavior, 31, (566-586).

Zagenczyk, T. J., Gibney, R., Few, W. T., \& Scott, K. L. (2011). Psychological contracts and organizational identification: The mediating effect of percieved organizational support. Journal of Labor Research, 32(3), 254-281. 